\title{
Metabotropic Glutamate Receptor-Mediated Cell Signaling Pathways Are Altered in a Mouse Model of Huntington's Disease
}

\author{
Fabiola M. Ribeiro, ${ }^{1 \star}$ Maryse Paquet, ${ }^{1 \star}$ Lucimar T. Ferreira, ${ }^{1}$ Tamara Cregan, ${ }^{1}$ Patrick Swan, ${ }^{1}$ Sean P. Cregan,,${ }^{1,2}$ \\ and Stephen S. G. Ferguson ${ }^{1,2}$ \\ ${ }^{1}$ Molecular Brain Research Group, Robarts Research Institute and 2Department of Physiology and Pharmacology, University of Western Ontario, London, \\ Ontario N6A 5K8, Canada
}

\begin{abstract}
Huntington's disease (HD) is an autosomal-dominant neurodegenerative disorder caused by a polyglutamine expansion in the huntingtin protein (Htt). Group I metabotropic glutamate receptors (mGluRs) are coupled to $\mathrm{G}_{\alpha \mathrm{q}}$ and play an important role in neuronal survival. We have previously demonstrated that mGluRs interact with Htt. Here we used striatal neuronal primary cultures and acute striatal slices to demonstrate that mGluR-mediated signaling pathways are altered in a presymptomatic mouse model of HD (Hdh $\left.{ }^{Q 111 / Q 111}\right)$, as compared to those of control mice $\left(H d h^{Q 20 / Q 20}\right)$. mGluR1/5-mediated inositol phosphate (InsP) formation is desensitized in striatal slices from $H d h^{Q 111 / Q 111}$ mice and this desensitization is PKC-mediated. Despite of decreased InsP formation, $(S)$-3,5-dihydroxylphenylglycine (DHPG)-mediated $\mathrm{Ca}^{2+}$ release is higher in $H d h^{Q 111 / Q 111}$ than in $H d h^{Q 20 / Q 20}$ neurons. Furthermore, mGluR1/5-stimulated AKT and extracellular signal-regulated kinase (ERK) activation is altered in $H d h^{Q 111 / Q 111}$ mice. Basal AKT activation is higher in $H d h^{Q 111 / Q 111}$ neurons and this increase is mGluR5 dependent. Moreover, mGluR5 activation leads to higher levels of ERK activation in $H d h^{Q 111 / Q 111}$ than in $H d h^{Q 20 / Q 20}$ striatum. PKC inhibition not only brings $H d h^{Q 111 / Q 111} \mathrm{DHPG}$-stimulated InsP formation to $H d h^{Q 20 / Q 20}$ levels, but also causes an increase in neuronal cell death in $H d h^{Q 111 / Q 111}$ neurons. However, PKC inhibition does not modify neuronal cell death in $H d h^{Q 20 / Q 20}$ neurons, suggesting that PKC-mediated desensitization of mGluR1/5 in $H d h^{Q 111 / Q 111}$ mice might be protective in HD. Together, these data indicate that group I mGluR-mediated signaling pathways are altered in HD and that these cell signaling adaptations could be important for striatal neurons survival.
\end{abstract}

\section{Introduction}

Huntington's disease (HD) is an autosomal-dominant neurodegenerative disorder caused by a progressive neuronal cell loss in the caudate-putamen and neocortical regions of the brain, which leads to involuntary body movement, loss of cognitive function, psychiatric disturbance, and death (Young, 2003; Li and Li, 2004). HD patients exhibit a polyglutamine expansion in the $\mathrm{N}$-terminal region of the huntingtin (Htt) protein, which is proposed to cause the neuronal cell loss observed in HD patients (The Huntington's Disease Collaborative Research Group, 1993).

Glutamate is postulated to play an important role in excitotoxic neuronal cell loss (DiFiglia, 1990; Nicoletti et al., 1996;

\footnotetext{
Received 0ct. 6, 2009; revised Nov. 5, 2009; accepted Nov. 9, 2009.

F.M.R. is the recipient of a Heart and Stroke Foundation of Canada (HSFC) Postdoctoral Fellowship. M.P. is the recipient of a Canadian Institutes of Health Research (CIHR) postdoctoral fellowship award. S.S.G.F. holds a Tier I Canada Research Chair in Molecular Neurobiology and is a Career Investigator of the Heart and Stroke Foundation of Ontario. This work was supported by CIHR Grant MA-15506 to S.S.G.F. We also thank Dr. Douglas Sheffler and Dr. Jeffrey Conn for helping us to establish a protocol for InsP formation assay in brain slices, as well as Dr. Stephen M. Sims and Tom Chrones for helping us to perform the calcium experiments.

*F.M.R. and M.P. contributed equally to this manuscript.

Correspondence should be addressed to Dr. Stephen S. G. Ferguson, Robarts Research Institute, University of Western Ontario, 100 Perth Drive, London, 0N N6A 5K8, Canada. E-mail: ferguson@robarts.ca.

DOI:10.1523/JNEUROSCI.4974-09.2010

Copyright $\odot 2010$ the authors $\quad 0270-6474 / 10 / 300316-09 \$ 15.00 / 0$
}

Calabresi et al., 1999). There are two types of glutamate receptors: ionotropic and metabotropic (Conn and Pin, 1997). Ionotropic glutamate receptors are ligand-gated ion channels, whereas metabotropic glutamate receptors (mGluRs) are members of the G-protein-coupled receptor (GPCR) superfamily (Nakanishi, 1994; Pin and Duvoisin, 1995; Conn and Pin, 1997; Dhami and Ferguson, 2006). Group I mGluRs (mGluR1 and mGluR5) are coupled to the activation of $\mathrm{G} \alpha_{\mathrm{q} / 11}$ proteins, which stimulate the activation of phospholipase $\mathrm{C} \beta 1$ (PLC $\beta 1$ ) resulting in diacylglycerol and inositol-1,4,5-triphosphate formation, release of $\mathrm{Ca}^{2+}$ from intracellular stores and activation of protein kinase $\mathrm{C}$ (PKC). mGluR1/5 stimulation also leads to activation of other signaling pathways important for cell survival/proliferation, such as extracellular signal-regulated kinase (ERK) and AKT (Rong et al., 2003; Hou and Klann, 2004; Mao et al., 2005).

Although glutamate receptors are thought to contribute to excitotoxic neuronal loss in HD, it is still unclear whether group I mGluRs activation could delay or accelerate HD, as different reports have published contradictory data (DiFiglia, 1990; Beal et al., 1991; Nicoletti et al., 1996; Bruno et al., 2001; Zeron et al., 2002; Tang et al., 2003; Schiefer et al., 2004). Recently, we determined that group I mGluRs interact with mutant Htt and that mGluR5 signaling was selectively uncoupled as a consequence of this interaction (Anborgh et al., 2005). Thus, it is possible that alterations of receptor-mediated signaling pathways could con- 

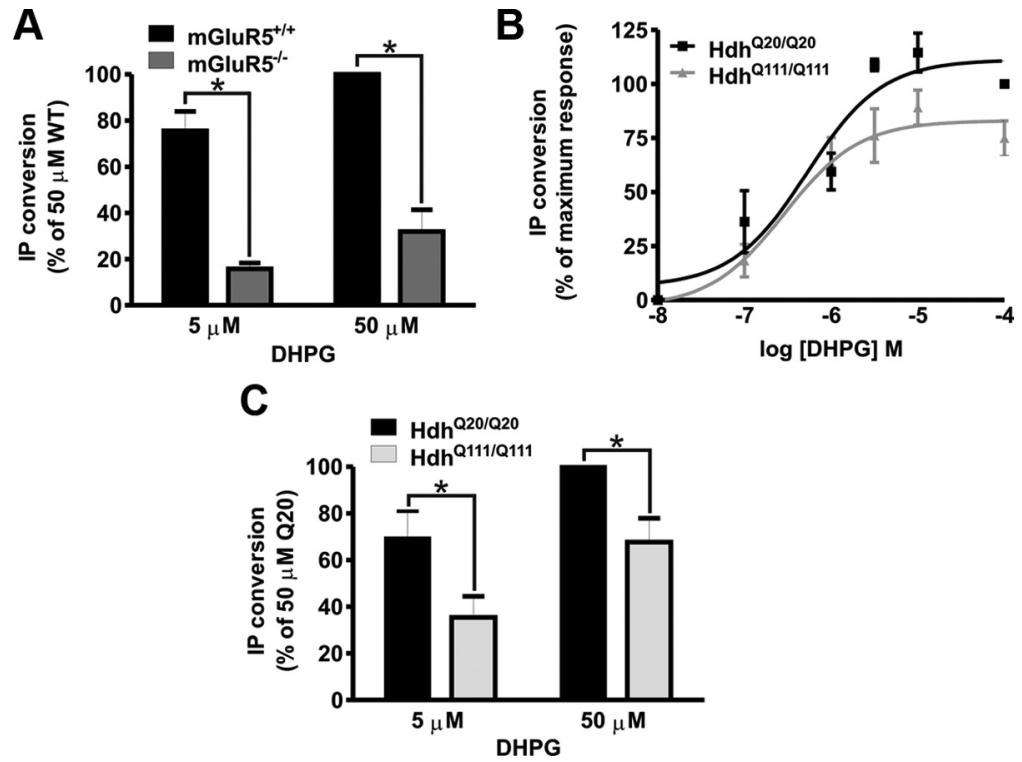

Figure 1. DHPG-stimulated InsP formation is decreased in $H_{d h} h^{0111 / 0111}$ mice. A, Shown is mGluR1/5-stimulated inositol phosphate formation in response to either 5 or $50 \mu \mathrm{M}$ DHPG for $15 \mathrm{~min}$ at $37^{\circ} \mathrm{C}$ in striatal slices from either mGluR5 $5^{-1-}$ or wild-type mice. Data represent the means \pm SEM of three independent experiments, expressed as percentage of DHPGstimulated wild-type slice maximum response. Asterisks indicate significant differences as compared to wild-type slices at the corresponding agonist concentration $(p<0.05)$. $\boldsymbol{B}$, Shown is DHPG-stimulated inositol phosphate formation in striatal neurons stimulated with increasing concentrations of agonist for $5 \mathrm{~min}$ at $37^{\circ} \mathrm{C}$. The data points represent the means \pm SEM of five independent experiments, expressed as percentage of $H d h^{020 / 020}$ maximum DHPG-stimulated response. C, Shown is mGluR1/5stimulated inositol phosphate formation in response to either 5 or $50 \mu \mathrm{M} \mathrm{DHPG} \mathrm{for} 15 \mathrm{~min}$ at $37^{\circ} \mathrm{C}$ in striatal slices from either $H d h^{020 / 020}$ or $H d h^{0111 / 0111}$ mice. Data represent the means \pm SEM of five independent experiments, expressed as percentage of DHPG-stimulated $H d h^{020 / 020}$ slice maximum response. Asterisks indicate significant differences as compared to $\mathrm{Hdh}^{020 / 020}$ slices at the corresponding agonist concentration $(p<0.05)$.
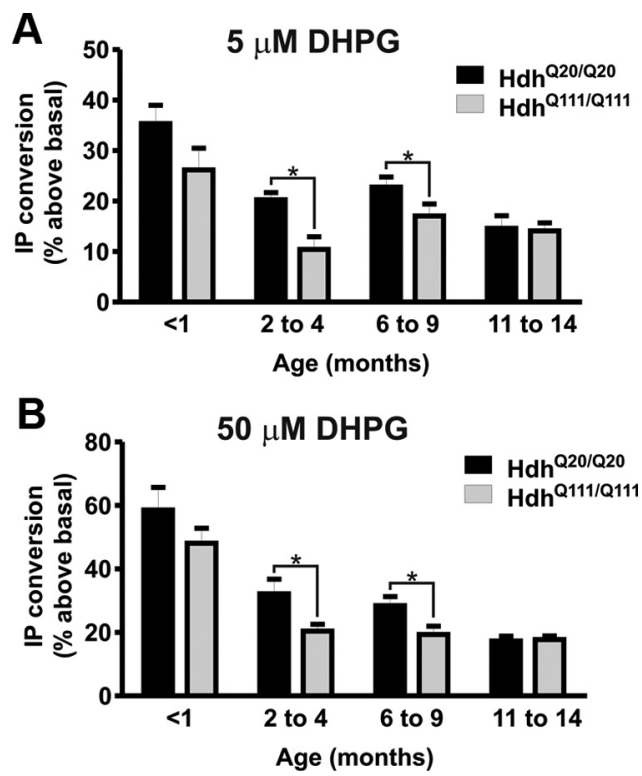

Figure 2. The decrease in $\mathrm{Hdh}{ }^{0111 / 0111}$ Ins P formation is only present in presymptomatic huntingtin mice. Shown is $\mathrm{mGluR} 1 / 5$-stimulated inositol phosphate formation in response to either $5 \mu \mathrm{M}(\boldsymbol{A})$ or $50 \mu \mathrm{m}(\boldsymbol{B})$ DHPG for $15 \mathrm{~min}$ at $37^{\circ} \mathrm{C}$ in striatal slices from either $\mathrm{Hdh} h^{020 / 020}$ or $\mathrm{Hdh}^{0111 / 0111}$ mice from different age groups. Asterisks indicate significant differences as compared to $\mathrm{Hdh}^{020 / 020}$ slices at the corresponding age group $(p<0.05)$.

tribute to protection or exacerbation of cell death cascades in the symptomatic and/or presymptomatic phases of HD. To investigate group I mGluRs activity in $\mathrm{HD}$, we studied different signaling pathways that can be activated by mGluR $1 / 5$ in both neuronal

Mouse model primary cultures and acute slices from the striatal brain region of a knock-in $\left(H d h^{Q 111 / Q 111}\right)$ mouse model of HD. We find that similar to what was previously reported for striatal neurons derived from YAC128 mice (Tang et al., 2005), $\mathrm{Ca}^{2+}$ signaling is generally disturbed in $H d h^{Q 111 / Q 111}$ mice. However, we find that mGluR1/5 inositol phosphate (InsP) formation is selectively uncoupled in neuronal cultures and slices derived from young $H d h^{Q 111 / Q 111}$ mice, as compared to control $H d h^{\mathrm{Q} 20 / \mathrm{Q} 20}$ mice, in a PKCdependent manner. Moreover, basal AKT and mGluR-mediated ERK1/2 phosphorylation is selectively increased in $H d h^{Q 111 /}$ Q111 mice. Our results indicate that dysregulation of $\mathrm{Ca}^{2+}$ signaling is a common feature of HD mouse models and that mGluR5 signaling pathways are altered in HD and the adaptation in cell signaling favors the activation of pathways that promote striatal neuronal survival.

\section{Materials and Methods}

\section{Materials}

(S)-3,5-dihydroxylphenylglycine (DHPG) was purchased from Tocris Cookson. Carbachol (carbamylcholine chloride) and dopamine were from Sigma-Aldrich. Bisindolylmaleimide I (Bis I) was purchased from Calbiochem. myo-

$\left[{ }^{3} \mathrm{H}\right]$ Inositol was acquired from PerkinElmer Life Sciences. The Dowex 1-X8 (formate form) resin with 200-400 mesh was purchased from Bio-Rad. Bovine serum albumin (BSA) was obtained from BioShop Canada. Horseradish peroxidase-conjugated antirabbit IgG secondary antibody was from Bio-Rad. ECL Western blotting detection reagents were from GE Healthcare. EZ-Link Sulfo-NHS-SSBiotin and immobilized NeutrAvidin beads were from Pierce Biotechnology. Fura-2 and Live/Dead viability assays were from Invitrogen. Rabbit anti-mGluR1 and anti-mGluR5 antibodies were from Millipore. Rabbit anti-phospho ERK, anti-phospho AKT, anti-ERK, and anti-AKT antibodies were from Cell Signaling Technology. Rabbit anti-actin antibody was from Santa Cruz Biotechnology. All other biochemical reagents were purchased from Sigma-Aldrich.

STOCK-Htt $t^{\text {tm2Mem }} / \mathrm{J}\left(H d h^{\mathrm{Q} 20 / \mathrm{Q} 20}\right)$ and STOCK-Htt $t^{t m 5 \mathrm{Mem}} / \mathrm{J}\left(H d h^{\mathrm{Q} 111 / \mathrm{Q} 111}\right)$ knock-in mice (Wheeler et al., 1999) and mGluR5 knock-out mice B6; 129-Grm5 $5^{\mathrm{tm} 1 \mathrm{Rod} / J}$ (mGluR5 ${ }^{-/-}$) (Lu et al., 1997) were purchased from Jackson Laboratory. $H d h^{\mathrm{Q} 111 / \mathrm{Q} 111} / \mathrm{mGluR}^{-1-}$ mice were obtained by crossing $H d h^{Q 111 / Q 111}$ and mGluR5 ${ }^{-1-}$ mice. Mice were housed in an animal care facility at $23^{\circ} \mathrm{C}$ on a $12 \mathrm{~h}$ light $/ 12 \mathrm{~h}$ dark cycle with food and water provided ad libitum. Animal care was in accordance with the University of Western Ontario Animal Care Committee.

\section{Neuronal primary culture preparation}

Neuronal cultures were prepared from the striatal region of E15 mouse embryo brains. Animal procedures were approved by The University of Western Ontario Animal Care Committee. After dissection, striatal tissue was submitted to trypsin digestion followed by cell dissociation using a fire-polished Pasteur pipette. Cells were plated on poly-L-ornithine coated dishes in neurobasal media supplemented with N2 and B27 supplements, $2 \mathrm{~mm}$ glutamax, $50 \mu \mathrm{g} / \mathrm{ml}$ penicillin, and $50 \mu \mathrm{g} / \mathrm{ml}$ streptomycin. Cells were incubated at $37^{\circ} \mathrm{C}$ and $5 \% \mathrm{CO}_{2}$ in a humidified incubator and cultured for 10 to $12 \mathrm{~d}$ in vitro (DIV) with media replenishment every $4 \mathrm{~d}$. 
Inositol phosphate formation assay

Neuronal primary culture. Inositol lipids were radiolabeled by incubating the striatal neuronal cultures from either $H d h^{\mathrm{Q} 20 / \mathrm{Q} 20}$ or $H d h^{Q 111 / Q 111}$ mice overnight with $1 \mu \mathrm{Ci} / \mathrm{ml}$ myo- $\left[{ }^{3} \mathrm{H}\right]$ inositol in Neurobasal medium. Unincorporated myo- $\left[{ }^{3} \mathrm{H}\right]$ inositol was removed by washing cells with Hank's balanced salt solution (HBSS). Cells were preincubated for $1 \mathrm{~h}$ in $\mathrm{HBSS}$ at $37^{\circ} \mathrm{C}$ and then preincubated in 500 $\mu l$ of the same buffer containing $10 \mathrm{~mm} \mathrm{LiCl}$ for an additional $2 \mathrm{~min}$ at $37^{\circ} \mathrm{C}$. Cells were then incubated in the presence of increasing concentrations of DHPG for $5 \mathrm{~min}$ at $37^{\circ} \mathrm{C}$, as indicated in the figures. The reaction was stopped on ice by the addition of $500 \mu \mathrm{l}$ of perchloric acid and then neutralized with $400 \mu \mathrm{l}$ of $0.72 \mathrm{M}$ $\mathrm{KOH}, 0.6 \mathrm{M} \mathrm{KHCO}_{3}$. Total $\left[{ }^{3} \mathrm{H}\right]$ inositol incorporated into cells was determined by counting the radioactivity present in $50 \mu \mathrm{l}$ of cell lysate. Total inositol phosphate was purified from cell extracts by anion exchange chromatography using Dowex 1-X8 (formate form) 200-400 mesh anion exchange resin. $\left[{ }^{3} \mathrm{H}\right]$ Inositol phosphate formation was determined by liquid scintillation.

Acute brain slices. InsP formation in striatal slices was measured as previously described (Alagarsamy et al., 2005). Dissected striata from age-matched $H d h^{\mathrm{Q} 20 / \mathrm{Q} 20}, H d h^{\mathrm{Q} 11 / \mathrm{Q} 111}$, or mGluR5 ${ }^{-1-}$ mice were cross-chopped with a McIlwain tissue chopper with a slice thickness of $350 \mu \mathrm{m}$. Resulting striatal prisms were recovered in ACSF $(127 \mathrm{~mm} \mathrm{NaCl}, 2 \mathrm{~mm} \mathrm{KCl}$, $10 \mathrm{~mm}$ glucose, $1.2 \mathrm{~mm} \mathrm{KH_{2 }} \mathrm{PO}_{4}, 26 \mathrm{~mm}$ $\mathrm{NaH}_{2} \mathrm{CO}_{3}, 1 \mathrm{~mm} \mathrm{MgSO}, 1 \mathrm{~mm} \mathrm{CaCl}, \mathrm{pH} 7.4$ ) gassed with $95 \% \mathrm{O}_{2} / 5 \% \mathrm{CO}_{2}$ and incubated in a shaking bath at $37^{\circ} \mathrm{C}$ for $30 \mathrm{~min} .20 \mu \mathrm{l}$ of gravity-packed prisms were aliquoted in duplicate samples, gassed, and incubated with $3 \mu \mathrm{Ci} / \mathrm{ml} m y o-\left[{ }^{3} \mathrm{H}\right]$ inositol in a shaking bath at $37^{\circ} \mathrm{C}$ for $90 \mathrm{~min}$. The prisms were gassed again and incubated in a shaking bath at $37^{\circ} \mathrm{C}$ for an additional $15 \mathrm{~min}$ in presence of $10 \mathrm{~mm} \mathrm{LiCl} \mathrm{before} \mathrm{they} \mathrm{were}$ stimulated with DHPG, dopamine or carbachol for $20 \mathrm{~min}$ in the same conditions. The reaction was stopped by adding $900 \mu \mathrm{l}$ of a 2:1 mix of chloroform:methanol and incubating for $15 \mathrm{~min}$ at room temperature. $300 \mu \mathrm{l}$ of chloroform was then added and samples were mixed vigorously. Total $\left[{ }^{3} \mathrm{H}\right]$ inositol incorporated into slices was determined by counting the radioactivity present in $200 \mu$ l of the hydrophobic layer. 700 $\mu \mathrm{l}$ of top aqueous layer was added to Dowex 1-X8 (formate form) $200-$ 400 mesh anion exchange resin. Columns were washed three times with water and twice with $60 \mathrm{~mm}$ ammonium formate. Samples were eluted with $200 \mathrm{~mm}$ ammonium formate $0.1 \mathrm{M}$ formic acid in scintillation vials containing scintillation fluid. $\left[{ }^{3} \mathrm{H}\right]$ Inositol phosphate formation was determined by liquid scintillation using a Beckman LS 6500 scintillation system (Dhami et al., 2002, 2005).

\section{Cell surface biotinylation assay}

Plasma membrane proteins of striatal prisms prepared as described above were biotinylated with sulfo-NHS-SS-biotin for $1 \mathrm{~h}$ on ice, as described previously (Ribeiro et al., 2007). To quench the biotinylation reaction, slices were washed and incubated for $30 \mathrm{~min}$ with cold $100 \mathrm{~mm}$ glycine in HBSS, followed by 3 washes with cold HBSS. Slices were then lysed in RIPA buffer (0.15 M NaCl, $0.05 \mathrm{~m}$ tris-HCl, pH 7.2, $0.05 \mathrm{~m}$ EDTA, $1 \%$ Nonidet P40, $1 \%$ Triton X-100, $0.5 \%$ sodium deoxycholate, $0.1 \%$ SDS) containing protease inhibitors ( $1 \mathrm{~mm}$ AEBSF and $10 \mu \mathrm{g} / \mathrm{ml}$ of both leupeptin and aprotinin). Biotinylated proteins were separated from nonbiotinylated proteins by NeutrAvidin bead pull-down from equivalent amounts of total cellular protein from each sample. Biotinylated
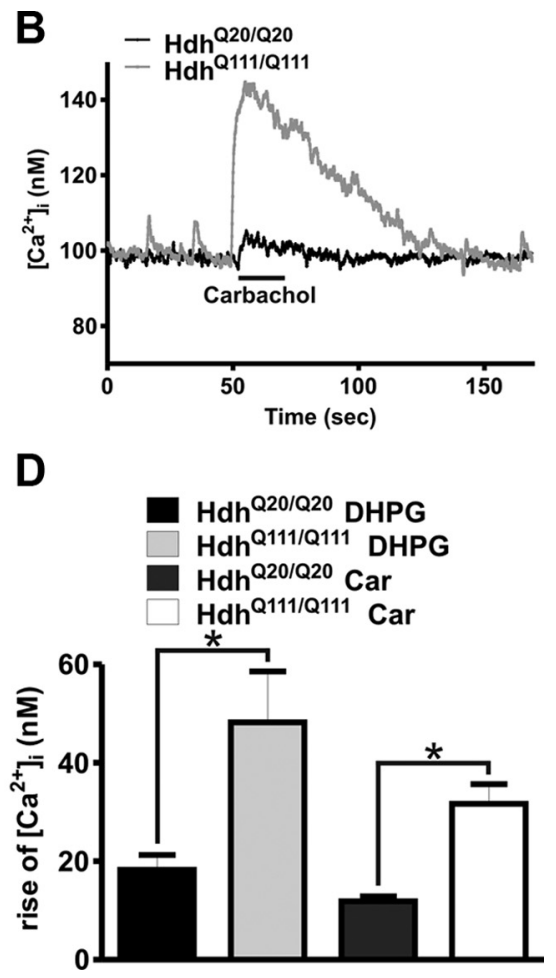

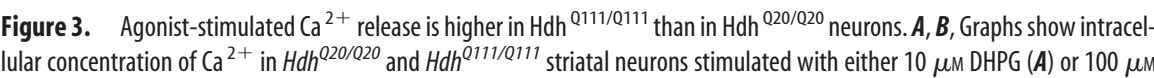
carbachol (B) for $20 \mathrm{~s}$ (indicated by the bar). $\boldsymbol{C}$, Graph shows the area under the curve (AUC) of the integrated $\mathrm{Ca}^{2+}$ responses to quantified as the maximal rise of $\left[\mathrm{Ca}^{2+}\right]_{i}$ above basal levels in $H d h^{020 / 020}$ and $H d h^{0111 / 0111}$ neurons. Data represent the means \pm SEM of five independent experiments and a total of 80 cells analyzed. Asterisks indicate significant differences as compared to $H d h^{Q 20 / Q 20}$ response $(p<0.05)$.

proteins were subjected to SDS-PAGE, followed by electroblotting onto nitrocellulose membranes.

\section{Immunoblotting}

Membranes were blocked with $10 \%$ milk in wash buffer $(150 \mathrm{~mm} \mathrm{NaCl}$, $10 \mathrm{~mm}$ Tris-HCl, pH 7.0, and $0.05 \%$ Tween 20) for $1 \mathrm{~h}$ and then incubated with rabbit anti-mGluR5 (1:4000), rabbit anti-mGluR1 (1:1000), or rabbit anti-actin $(1: 10,000)$ antibodies in wash buffer containing $3 \%$ milk overnight. Membranes were rinsed three times with wash buffer and then incubated with secondary horseradish peroxidase-conjugated goat anti-rabbit IgG diluted 1:10,000 in wash buffer containing 3\% skim milk for $1 \mathrm{~h}$. Membranes were rinsed three times with wash buffer and incubated with ECL Western blotting detection reagents.

\section{ERK and $A K T$ activation experiments}

Neuronal primary culture. Neuronal primary cultures from $H d h^{\mathrm{Q} 20 / \mathrm{Q} 20}$ and $H d h^{Q 111 / Q 111}$ embryos were incubated in HBSS for $30 \mathrm{~min}$ at $37^{\circ} \mathrm{C}$. Cultures were then stimulated with $10 \mu \mathrm{M}$ DHPG for 0,2 or 5 min at $37^{\circ} \mathrm{C}$. When 2-methyl-6-(phenylethynyl)-pyridine (MPEP) was used, it was added before and kept during DHPG stimulation. Neurons were lysed in RIPA buffer containing protease inhibitors ( $1 \mathrm{~mm}$ AEBSF and 10 $\mu \mathrm{g} / \mathrm{ml}$ of both leupeptin and aprotinin). $50 \mu \mathrm{g}$ of total cellular protein for each sample were subjected to SDS-PAGE, followed by electroblotting onto nitrocellulose membranes. Immunoblot was performed as described above. Membranes were blocked with $10 \%$ milk in wash buffer for $1 \mathrm{~h}$ and then incubated with either rabbit anti-phospho ERK (1:1000) or rabbit anti-phospho AKT (S473) (1:1000) antibodies in wash buffer containing 3\% milk overnight. Membranes were probed with secondary horseradish peroxidase-conjugated goat anti-rabbit and incubated with ECL Western blotting detection reagents as described above. Antibodies were then stripped and membranes were incubated with anti-ERK (1: $1000)$ and anti-AKT (1:1000) overnight and probed with secondary an- 
tibody to determine total kinase expression. Immuno-band intensity was quantified and the number of pixels of ERK and AKT phospho-bands was divided by the number of pixels of total ERK and AKT, respectively, to normalize phosphorylation levels of kinases to total kinase expression.

Acute brain slices. $350 \mu \mathrm{m}$ thick coronal slices from age-matched $H d h^{\mathrm{Q} 20 / \mathrm{Q} 20}$ and $H d h^{\mathrm{Q} 111 / \mathrm{Q} 111}$ mouse brains were prepared using a Vibratome system (Leica). The striatal region was dissected and slices were recovered in ACSF gassed with $95 \% \mathrm{O}_{2} / 5 \% \mathrm{CO}_{2}$ and incubated at $30^{\circ} \mathrm{C}$ for $90 \mathrm{~min}$. Slices were transferred to tubes in duplicate samples, gassed, and kept at $30^{\circ} \mathrm{C}$ for $30 \mathrm{~min}$. After this incubation, slices were stimulated with DHPG at $30^{\circ} \mathrm{C}$ for $30 \mathrm{~min}$. Slices were snap-frozen in ethanol/dry ice bath and lysed in RIPA buffer containing protease and phosphatase inhibitors. $100 \mu \mathrm{g}$ of total cellular protein for each sample were subjected to SDS-PAGE, followed by electroblotting onto nitrocellulose membranes. Immunoblot was performed as described above to detect phospho- and total-ERK.

\section{Cell death assay}

Neurons were incubated for $24 \mathrm{~h}$ with either vehicle or drug $(250 \mu \mathrm{M}$ glutamate, $100 \mu \mathrm{M}$ DHPG, $1 \mu \mathrm{M}$ Bis I, or $100 \mu \mathrm{M}$ DHPG along with $1 \mu \mathrm{M}$ Bis I), as indicated in Figure 7 legend, and cell death was determined by Live/Dead viability assay, as described previously (Fortin et al., 2001). Briefly, neurons were stained with Calcein-AM $(2 \mu \mathrm{M})$ and ethidium homodimer $(2 \mu \mathrm{M})$ for $15 \mathrm{~min}$ and the fraction of live (Calcein-AM positive) and dead (ethidium positive) cells were determined. Neurons were visualized by fluorescence microscopy (IX70; Olympus) and images were captured with a CCD camera (Q-Imaging) and Northern Eclipse software (Empix Imaging). Images were captured and scored by a blinded observer and a minimum of 300 cells were analyzed per well in duplicate. Dead cells were expressed as a percentage of the total number of cells.

\section{Measurement of $\left[\mathrm{Ca}^{2+}\right]_{i}$}

Neuronal primary cultures from $H d h^{\mathrm{Q} 20 / \mathrm{Q} 20}$ and $H d h^{\mathrm{Q} 111 / \mathrm{Q} 111}$ embryos seeded on $12 \mathrm{~mm}$ coverslips were loaded with $0.2 \mu \mathrm{M}$ fura- 2 acetoxymethyl ester (AM) for $20 \mathrm{~min}$ at $37^{\circ} \mathrm{C}$. Coverslips were mounted on a Nikon inverted microscope and perfused with HBSS at $1-3 \mathrm{ml} / \mathrm{min}$ at room temperature. Neurons were stimulated with either $10 \mu \mathrm{M}$ DHPG or $100 \mu \mathrm{M}$ carbachol and illuminated with alternating 345 and $380 \mathrm{~nm}$ light using a Deltascan system (Photon Technology International), with the $510 \mathrm{~nm}$ emission detected using a photometer. Baseline (3-5 min) measurements were obtained before pulse of agonist. DHPG-induced $\mathrm{Ca}^{2+}$ responses were measured in either normal HBSS or $\mathrm{Ca}^{2+}$-free HBSS (omitted $\mathrm{CaCl}_{2}$ from HBSS and supplemented with $100 \mu \mathrm{M}$ EGTA). $\left[\mathrm{Ca}^{2+}\right]_{\mathrm{i}}$ was calibrated using the method of Grynkiewicz et al. (1985).

\section{Quantitative RT-PCR}

RNA was isolated using Trizol reagent as per manufacture's instructions (Invitrogen) and RNA concentration was measured on a spectrophotometer. Quantitative RT-PCR was performed using the QuantiFast SYBR Green RT-PCR kit (Qiagen) and 40 ng of RNA was used. RT-PCR was performed on a Chromo4 detection system (MJ Research/Bio-Rad) and changes in gene expression were determined by the $\Delta\left(\Delta C_{\mathrm{t}}\right)$ method using the ribosomal S12 transcript for normalization. Data are reported as fold increase in mRNA levels for each sample relative to that of 4 months old $H d h^{\mathrm{Q} 20 / \mathrm{Q} 20}$ mice. All PCRs exhibited high amplification efficiency $(>90 \%)$ and the specificity of PCR products were confirmed by sequencing. Primer sequences used for gene specific amplification are available on request.

\section{Data analysis}

Nonsaturated, immunoreactive mGluR5 bands from cell surface biotinylation assay and ERK and AKT bands were quantified by scanning densitometry using Scion Image software. Means \pm SEM are shown for the number of independent experiments indicated in the figure legends. GraphPad Prism software was used to analyze data for statistical significance and for curve fitting. Statistical significance was determined by ANOVA testing followed by post hoc Multiple Comparison testing.

\section{A \\ 2 to 4 month old mice}
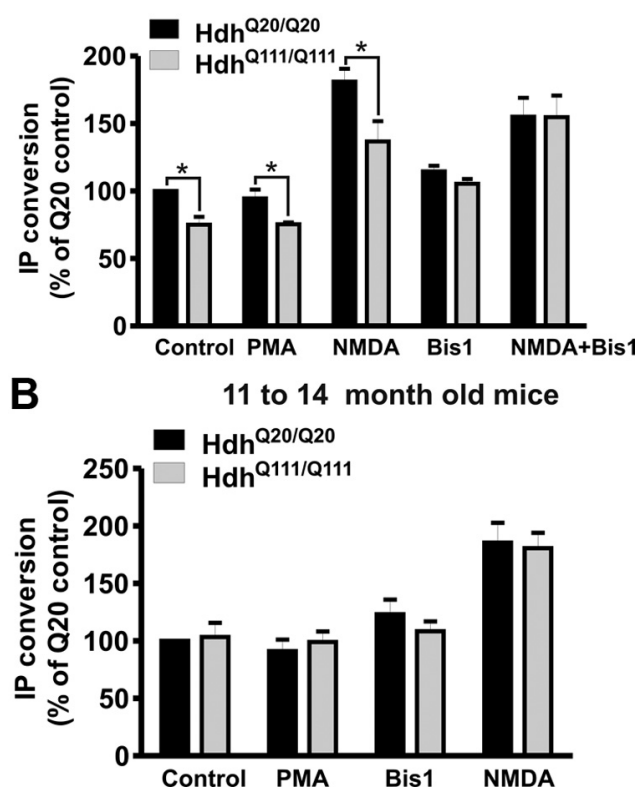

Figure 4. The decrease in InsP formation in $H d h^{Q 111 / Q 111}$ mice is PKC dependent. $A, B$, Shown is mGluR1/5-stimulated inositol phosphate formation in response to $50 \mu \mathrm{M}$ DHPG for $15 \mathrm{~min}$ at $37^{\circ} \mathrm{C}$ in striatal slices from either $H d h^{Q 20 / 020}$ or $H d h^{0111 / 0111}$ mice that were 2-4 $(\boldsymbol{A})$ or 11-14 months old $(\boldsymbol{B})$. Vehicle alone or vehicle plus indicated drug [PMA, NMDA, bisindolylmaleimide I (Bis1), or NMDA + Bis1] were added to slices 15 min before DHPG stimulation. Data represent the means \pm SEM of six independent experiments, expressed as percentage of DHPG-stimulated $\mathrm{Hdh}^{020 / Q 20}$ slices (control). Asterisks indicate significant differences as compared to matched treated $H d h^{020 / 020}$ slices $(p<0.05)$.

\section{Results}

\section{mGluR1/5 mediated InsP formation is attenuated in} $\mathrm{Hdh}^{\mathrm{Q11} / \mathrm{Q111}}$ mice

Both mGluR1 and mGluR5 are expressed in medium sized spiny striatal neurons, which are the neurons that die selectively in HD (Vonsattel et al., 1985; Romano et al., 1995). Previously, we demonstrated that mGluR5 was the primary group I mGluR expressed in primary cultured striatal neurons (12-15 DIV) obtained from E15 embryos (Ribeiro et al., 2009). To determine which group I mGluR was the primary receptor responsible for DHPG-stimulated InsP formation in adult mice, we stimulated striatal slices from either wild-type or mGluR $5^{-1-}$ mice with 5 or $50 \mu \mathrm{M}$ DHPG and determined InsP formation. Striatal slices from mGluR5 ${ }^{-1-}$ mice exhibited only $\sim 20-30 \%$ of wild-type DHPG-mediated InsP formation, indicating that mGluR5 was the primary $\mathrm{G}_{\mathrm{q} / 11}$-coupled $\mathrm{mGluR}$ in the striatum of adult mice (Fig. 1A).

To determine whether mGluR1/5 activity was altered in HD, we measured InsP formation in primary cultured striatal neurons that were stimulated with increasing concentrations of DHPG (Fig. $1 B$ ). The maximum response for DHPG-stimulated InsP formation in $H d h^{Q 111 / Q 111}$ neurons was $74.7 \pm 9.5 \%$ of that of $H d h^{Q 20 / Q 20}$ neurons, and the half-maximal effective concentration $\left(\mathrm{EC}_{50}\right)$ for the agonist was the same in neurons from both $H d h^{Q 111 / Q 111}$ and $H d h^{Q 20 / Q 20}$ mice (Fig. $1 B$ ). In acute striatal slices from 2- to 4-month-old $H d h^{\mathrm{Q} 20 / \mathrm{Q} 20}$ or $H d h^{\mathrm{Q} 111 / \mathrm{Q} 111}$ mice treated with either 5 or $50 \mu \mathrm{M}$ DHPG, InsP formation was significantly reduced in $H d h^{Q 111 / Q 111}$ mice, as compared to that of $H d h^{Q 20 / Q 20}$ mice (Fig. 1C). There was no difference in basal InsP formation between $H d h^{\text {Q111/Q111 }}$ and $H d h^{\text {Q20/Q20 }}$ mice (data not shown). The reduction in InsP formation in $H d h^{\mathrm{Q} 111 / \mathrm{Q} 111}$ mice 
was specific to mGluR1/5, as slices stimulated with either $100 \mu \mathrm{M}$ carbachol, a cholinergic agonist, or $1 \mathrm{~mm}$ dopamine exhibited similar levels of InsP formation in both $H d h^{Q 20 / Q 20}$ and $H d h^{Q 111 / Q 111}$ striatal slices. Carbachol promoted $120 \pm 16 \%$ and $124 \pm 13 \%$ InsP formation over basal in $H d h^{Q 20 / Q 20}$ and $H d h^{Q 111 / Q 111}$ striatal slices, respectively; and dopamine stimulated $36 \pm 6 \%$ and $31 \pm 5 \%$ InsP formation over basal in $H d h^{\mathrm{Q} 20 / \mathrm{Q} 20}$ and $H d h^{Q 111 / Q 111}$ striatal slices, respectively. Thus, only agonist-stimulated mGluR5 InsP formation was reduced in $H d h^{Q 111 / Q 111}$ striatal slices.

$\mathrm{HD}$ is a progressive neurodegenerative disorder and its symptoms first appear in midlife, although the mutated Htt protein is present since the beginning of the patient's life (Vonsattel et al., 1985; The Huntington's Disease Collaborative Research Group, 1993; Vonsattel and DiFiglia, 1998). It is possible that either protective pathways are activated or that cell death signals are attenuated in the presymptomatic phase of the disease. To test whether mGluR1/5-mediated InsP formation was altered with age, we determined InsP formation in $\mathrm{Hdh}^{\mathrm{Q} 20 / \mathrm{Q} 20}$ and $H d h^{Q 111 / Q 111}$ mice of different age groups. mGluR1/5-mediated InsP formation was attenuated in presymptomatic $H d h^{Q 111 / Q 111}$ mice (up to 9 months old mice), as compared to age matched $H d h^{\mathrm{Q} 20 / \mathrm{Q} 20}$ mice, when slices were stimulated with either 5 $\mu \mathrm{M}$ (Fig. $2 A$ ) or $50 \mu \mathrm{M}$ DHPG (Fig. $2 B$ ). However, this difference in InsP formation between $H d h^{\mathrm{Q} 20 / \mathrm{Q} 20}$ and $H d h^{\mathrm{Q} 111 / \mathrm{Q} 111}$ mice was not present in mice older than 11 months (Fig. $2 A, B$ ). Interestingly, the extent of DHPG-stimulated InsP formation significantly waned in the $H d h^{\text {Q20/Q20 }}$ mice with such that at 11 months of age InsP formation was indistinguishable from the $H d h^{Q 111 / Q 111}$ mice. These data indicated that Group I mGluR signaling can be differently modulated in $H d h^{Q 111 / Q 111}$ mice and that its modulation can vary with age.

\section{mGluR1/5 protein expression is not different between} $H d h^{Q 20 / Q 20}$ and $H d h^{Q 111 / Q 111}$ mice

The decreased levels of DHPG-stimulated InsP formation in $H d h^{Q 11 / Q 111}$ mice could be due to diminished mGluR1/5 protein expression levels. To investigate this possibility, we determined mGluR1/5 total cell lysate expression and mGluR5 plasma membrane expression by performing a cell surface biotin labeling assay using striatal slices. mGluR1 overall expression was too low to allow plasma membrane expression measurements. Striatal slices of $H d h^{Q 20 / Q 20}$ and $H d h^{\text {Q111/Q111 }}$ mice from different age groups exhibited the same levels of mGluR1 and mGluR5 protein expression (supplemental Fig. 1A-C, available at www.jneurosci.org as supplemental material). Furthermore, mGluR5 plasma membrane expression was also identical in striatal slices from $H d h^{\mathrm{Q} 20 / Q^{20}}$ and $H d h^{\mathrm{Q} 111 / \mathrm{Q} 111}$ mice (supplemental Fig. $1 D$, available at www.jneurosci.org as supple-

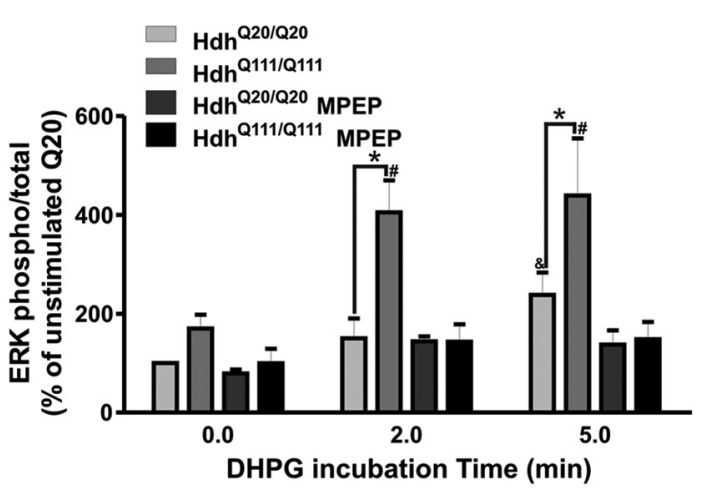

D

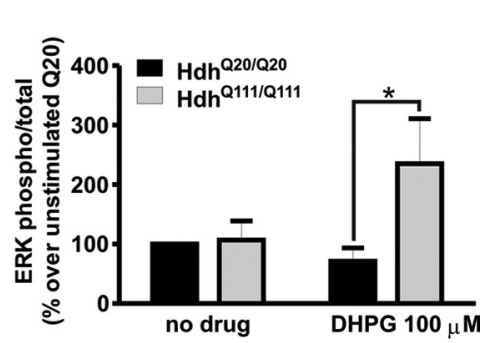

Figure 5. mGluR5-stimulated ERK1/2 phosphorylation is more elevated in $H d h^{Q 111 / Q 111}$ than in $H d h^{Q 20 / Q 20}$ mice. $A$, Shown is a representative immunoblot for phospho- (upper panel) and total-ERK expression (lower panel) in primary cultured striatal (a)

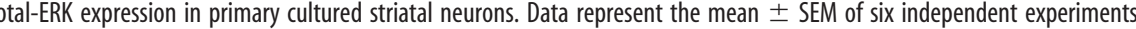

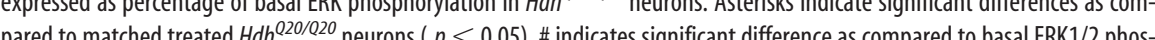
phorylation levels ( $p<0.05$ ). C, Shown is a representative immunoblot for phospho- (upper panel) and total-ERK expression (lower panel) in striatal slices from either $\mathrm{Hdh}^{020 / 020}$ or $\mathrm{Hdh}^{0111 / 0111}$ mice stimulated with $100 \mu \mathrm{M}$ DHPG for $30 \mathrm{~min}$. $100 \mu \mathrm{g}$ of cell sate is used for each sample. $\boldsymbol{D}$, Graph shows the densitometric analysis of phospho-ERK normalized to total-ERK expression in striatal slices. Data represent the mean \pm SEM of five independent experiments, expressed as percentage of basal ERK phosphorylation in $H d h^{Q 20 / Q 20}$ slices. Asterisk indicates significant difference as compared to matched treated $H d h^{Q 20 / 020}$ slices $(p<0.05)$.

mental material). mGluR5 plasma membrane expression was $16 \pm 3 \%$ and $15 \pm 2 \%$ of total cell lysate mGluR5 expression in $H d h^{\mathrm{Q} 20 / \mathrm{Q} 20}$ and $H d h^{Q 111 / Q 111}$ striatal slices, respectively. Therefore, the difference in DHPG-stimulated InsP formation between $H d h^{\mathrm{Q} 20 / \mathrm{Q} 20}$ and $H d h^{Q 111 / Q 111}$ mice could not be explained by differences in $\mathrm{mGluR} 1 / 5$ protein expression levels.

\section{$\mathrm{Ca}^{2+}$ release is increased in $\mathrm{Hdh}^{\mathrm{Q111/Q111}}$ neurons}

It was previously demonstrated that $\mathrm{Ca}^{2+}$ release from intracellular stores was dysregulated in medium spiny neurons derived from YAC128 transgenic HD mouse models (Tang et al., 2003, 2005). Thus, we tested whether the dysregulation of $\mathrm{Ca}^{2+}$ signaling observed in the YAC128 HD mouse might be a common feature of HD mouse models and was also observed in $H d h^{Q 111 / Q 111}$ mice. We used Fura-2 to measure $\mathrm{Ca}^{2+}$ release in response to either $10 \mu \mathrm{M}$ DHPG or $100 \mu \mathrm{M}$ carbachol treatments in primary striatal neurons derived from $H d h^{Q 20 / Q 20}$ and $H d h^{Q 111 / Q 111}$ mice. Despite the observed decrease in DHPG-mediated InsP formation in $H d h^{Q 11 / Q 111}$ neurons, DHPG-stimulated $\mathrm{Ca}^{2+}$ release was sig- 
nificantly exaggerated in $H d h^{Q 111 / Q 111}$ when compared to DHPG-stimulated $\mathrm{Ca}^{2+}$ release in $H d h^{\mathrm{Q} 20 / \mathrm{Q} 20}$ neurons (Fig. $3 A$ ). Carbachol treatment, which induced similar levels of InsP formation in $H d h^{Q 20 / Q 20}$ and $H d h^{Q 111 / Q 111}$ mice, also resulted in increased $\mathrm{Ca}^{2+}$ release in $H d h^{\mathrm{Q} 111 / \mathrm{Q} 111}$ neurons when compared to $H d h^{\mathrm{Q} 20 / \mathrm{Q} 20}$ neurons (Fig. 3B). Both the area under the curve and the maximum rise in $\mathrm{Ca}^{2+}$ concentration for both DHPG- and carbachol-induced $\mathrm{Ca}^{2+}$ release were significantly elevated in $H d h^{\mathrm{Q} 11 / \mathrm{Q} 111}$ neurons when compared to $H d h^{\mathrm{Q} 20 / \mathrm{Q} 20}$ neurons (Fig. 3C,D). In the presence of EGTA to chelate extracellular $\mathrm{Ca}^{2+}$, both the area under the curve $(268 \pm 75 \mathrm{~nm}$.sec and $540 \pm$ 115 nM.sec for $H d h^{Q 20 / Q 20}$ and $H d h^{Q 111 / Q 111}$ striatal neurons, respectively) and the maximum rise in $\mathrm{Ca}^{2+}$ concentration for DHPG-stimulated $\mathrm{Ca}^{2+}$ release $(6 \pm 1 \mathrm{nM}$ and $15 \pm 2 \mathrm{nM}$ for $H d h^{Q 20 / Q 20}$ and $H d h^{Q 111 / Q 111}$ striatal neurons, respectively) were significantly enhanced in $H d h^{Q 111 / Q 111}$ neurons when compared to $H d h^{Q 20 / Q 20}$ neurons. These data suggested that the increased release of $\mathrm{Ca}^{2+}$ was due to the sensitization of $\mathrm{Ca}^{2+}$ release from intracellular stores.

\section{Decreased InsP formation in $H d h^{Q 111 / Q 111}$ mice is PKC dependent}

$H d h^{Q 20 / Q 20}$ and $H d h^{Q 111 / Q 111}$ exhibited the same levels of mGluR1/5 protein expression at the cell surface and $\mathrm{Ca}^{2+}$ release was dysregulated in $H d h^{Q 111 / Q 111}$ neurons. Therefore, we hypothesized that mGluR1/5 InsP formation in $H d h^{Q 111 / Q 111}$ striatal neurons may be the consequence of increased PKC-mediated receptor desensitization. Group I mGluRs was previously shown to be desensitized by PKC (Catania et al., 1991). Therefore, we examined whether mGluR1/5-stimulated InsP formation in $H d h^{Q 111 / Q 111}$ striatal slices might be altered by the treatment of striatal slices with drugs that either activate or inactivate PKC. Similar to what we demonstrated in the earlier experiments, DHPG-stimulated InsP formation in striatal slices prepared from 2- to 4-month-old $H d h^{\mathrm{Q} 111 / \mathrm{Q} 111}$ mice was significantly attenuated when compared to slices prepared from 2- to 4-month-old $H d h^{\mathrm{Q} 20 / \mathrm{Q} 20}$ mice (Fig. 4A). The observed differences in InsP formation in striatal slices derived from $H d h^{Q 111 / Q 111}$ versus $H d h^{\mathrm{Q} 20 / \mathrm{Q} 20}$ mice was not affected by the activation of PKC with the phorbol ester PMA (Fig. 4A). However, the treatment of slices prepared from 2- to 4-month-old mice with bisindolylmaleimide I (Bis I) to inhibit PKC abolished the difference in InsP formation observed between $H d h^{\mathrm{Q} 20 / \mathrm{Q} 20}$ and $H d h^{\mathrm{Q} 111 / \mathrm{Q} 111}$ slices (Fig. 4A). It was previously shown that NMDA receptor activation could lead to resensitization of mGluR5 signaling (Alagarsamy et al., 1999). Therefore, we tested whether the treatment of slices derived from 2- to 4-month-old mice with $10 \mu \mathrm{M}$ NMDA would reverse the PKC-mediated desensitization observed in $H d h^{Q 111 / Q 111}$ mice. NMDA treatment increased DHPGmediated InsP formation in both $H d h^{Q 20 / Q 20}$ and $H d h^{Q 111 / Q 111}$ mice, but InsP formation remained reduced in $H d h^{Q 111 / Q 111}$ slices, as compared to that of $H d h^{Q 20 / Q 20}$ slices (Fig. $4 A$ ). The difference in DHPG-stimulated InsP formation between $H d h^{\mathrm{Q} 20 / \mathrm{Q} 20}$ and $H d h^{Q 111 / Q 111}$ was only eliminated when slices were incubated with both $10 \mu \mathrm{M}$ NMDA and $1 \mu \mathrm{M}$ Bis I (Fig. $4 A$ ). No difference in DHPG-stimulated InsP formation was observed in slices derived from 11 - to 14 -month-old $H d h^{\mathrm{Q} 20 / \mathrm{Q} 20}$ and $H d h^{\mathrm{Q} 111 / \mathrm{Q} 111}$ mice following any drug treatments, except that NMDA treatment increased DHPG-stimulated InsP formation in slices from either mouse line (Fig. 4B). The increased PKC-mediated mGluR1/5 desensitization observed in $H d h^{\text {Q111/Q111 }}$ mice could be the consequence of both $\mathrm{Ca}^{2+}$ dysregulation and alterations in
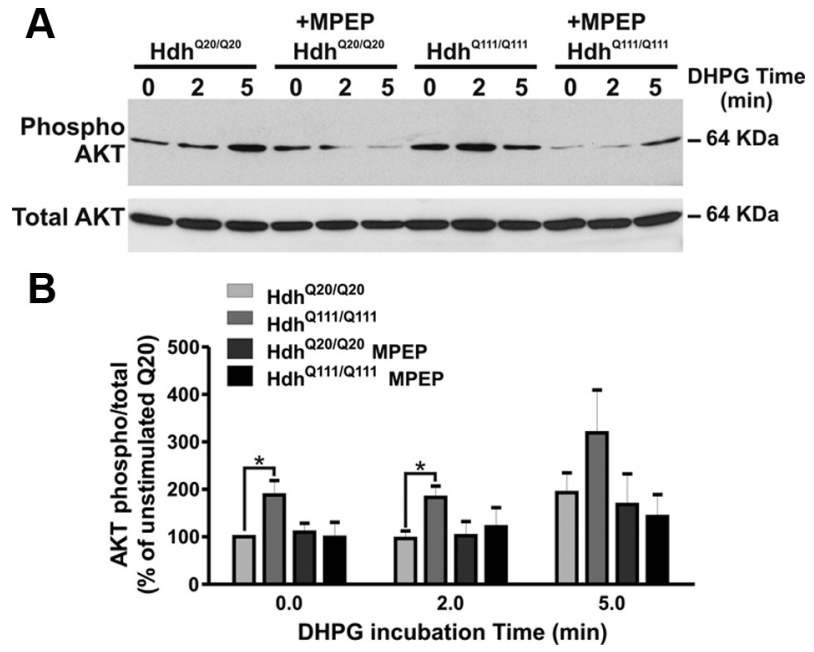

Figure 6. mGluR5-dependent basal AKT phosphorylation is higher in Hdh Q111/Q111 than in $H_{d h}{ }^{Q 20 / Q 20}$ neurons. $\boldsymbol{A}$, Shown is a representative immunoblot for phospho- (upper panel) and total-AKT expression (lower panel) in primary cultured striatal neurons from either $H d h^{020 / 020}$ or $H d h^{0111 / Q 111}$ mice stimulated with $10 \mu \mathrm{M}$ DHPG for 0,2 , or 5 min in presence or absence of $10 \mu \mathrm{m}$ MPEP. $50 \mu \mathrm{g}$ of cell lysate is used for each sample. $\boldsymbol{B}, \mathrm{Graph}$ shows the densitometric analysis of phospho-AKT normalized to total-AKT expression in primary cultured striatal neurons. Data represent the mean \pm SEM of six independent experiments, expressed as percentage of basal AKT phosphorylation in $H_{d h^{020 / 020}}$ neurons. Asterisks indicate significant differences as compared to matched treated $H_{d h}{ }^{020 / 020}$ neurons $(p<0.05)$.

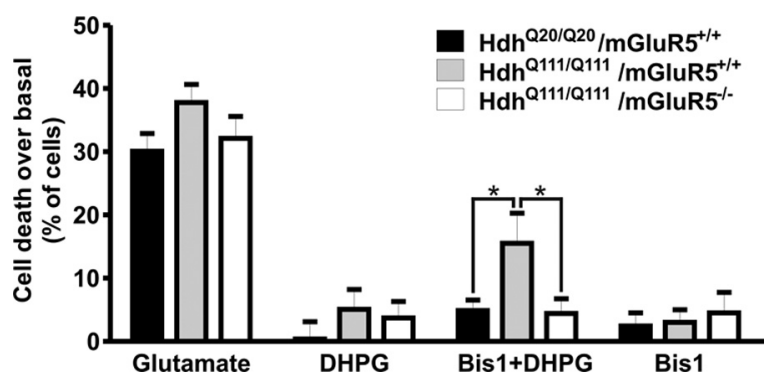

Figure 7. Inhibition of PKC-mediated mGluR5 desensitization causes an increase in cell death. Graph shows percentage of drug-induced cell death in striatal neurons from $\mathrm{Hdh}^{020 / 020}$ mGluR5 ${ }^{+/+},{ }_{\text {Hdh }} \mathrm{Q111}^{0111} / \mathrm{mGluR5}^{+/+}$or $H d h^{0111 / Q 111} / \mathrm{mGluR5}^{-/-}$mice. Striatal neuronal cultures were incubated with $250 \mu \mathrm{m}$ glutamate, $100 \mu \mathrm{m} \mathrm{DHPG}, 1 \mu \mathrm{m}$ Bis 1 or $100 \mu \mathrm{m}$ DHPG +1 $\mu \mathrm{m}$ Bis 1 for $24 \mathrm{~h}$. Data represent the means \pm SEM of six to seven independent experiments. Asterisks indicate significant difference in $H d h^{0111 / 0111} / \mathrm{mGluR5}^{+/+}$cell death as compared to $H d h^{Q 20 / Q 20} / \mathrm{mGluR5}^{+/+}$and $H d h^{0111 / 0111} / \mathrm{mGluR5}^{-/-}$neuronal cell death $(p<0.05)$.

PKC expression in $H d h^{Q 111 / Q 111}$ mice. To test whether PKC expression was altered in $H d h^{Q 111 / Q 111}$ mice, we performed real time RT-PCR to determine expression of different $\mathrm{Ca}^{2+}$-regulated PKC isoforms ( $\mathrm{PKC} \alpha, \beta$, and $\gamma$ ) in striatal tissue obtained from $H d h^{\mathrm{Q} 20 / \mathrm{Q} 20}$ and $H d h^{\mathrm{Q} 111 / \mathrm{Q} 111}$ mice from different age groups (4-, 9-, and 13-month-old mice). No difference in PKC mRNA expression was observed between $H d h^{\mathrm{Q} 20 / \mathrm{Q} 20}$ and $H d h^{\mathrm{Q} 111 / \mathrm{Q} 111}$ mice from any of the age groups tested (supplemental Fig. 2, available at www. jneurosci.org as supplemental material). Together, these data indicated that the difference in mGluR1/5-dependent InsP formation between $H d h^{\mathrm{Q} 20 / \mathrm{Q} 20}$ and $H d h^{\mathrm{Q} 111 / \mathrm{Q} 111}$ mice was due to increased PKC-mediated desensitization in $H d h^{Q 111 / Q 111}$ mice that may occur as the consequence of dysregulated $\mathrm{Ca}^{2+}$ release from intracellular stores. 
mGluR5 can activate protective signaling pathways in $H d h^{Q 111 / Q 111}$ neurons

Given that both InsP formation and $\mathrm{Ca}^{2+}$ release in response to mGluR1/5 activation is altered in $H d h^{Q 111 / Q 111}$ mice, we tested whether other signaling pathways activated by mGluRs might be altered in the $H d h^{Q 111 / Q 111}$ mice. For example, mGluR1/5 activation were previously shown to promote the phosphorylation and activation of both ERK1/2 and AKT (Datta et al., 1999; Grewal et al., 1999; Kandel and Hay, 1999). Primary cultured striatal neurons from $H d h^{\mathrm{Q} 20 / \mathrm{Q} 20}$ mouse embryos exhibited increased ERK1/2 phosphorylation following $5 \mathrm{~min}$, but not 2 min, DHPG stimulation (Fig. $5 A, B$ ). However, an increase in ERK $1 / 2$ phosphorylation in $H d h^{Q 111 / Q 111}$ neurons was observed as early as within 2 min DHPG stimulation, indicating that mGluRmediated ERK1/2 activation occurs more rapidly in $H d h^{Q 111 / Q 111}$ neurons, as compared to that of $H d h^{\mathrm{Q} 20 / \mathrm{Q} 20}$ neurons (Fig. $5 A, B)$. Moreover, ERK1/2 activation in response to $10 \mu \mathrm{M}$ DHPG treatment for 2 and 5 min was significantly greater in $H d h^{Q 111 / Q 111}$ neurons when compared with $H d h^{Q 20 / Q 20}$ neurons (Fig. 5A,B). The enhanced activation of ERK1/2 in $H d h^{Q 111 / Q 111}$ neurons by DHPG was mGluR5-dependent, as the treatment of neurons with the mGluR5 selective antagonist MPEP $(10 \mu \mathrm{M})$ mitigated the observed difference in ERK1/2 phosphorylation between $H d h^{Q 20 / Q 20}$ and $H d h^{Q 111 / Q 111}$ neurons (Fig. $5 A, B$ ). Similar results were obtained in striatal slices, as an increase in ERK1/2 phosphorylation was observed following DHPG stimulation of $H d h^{Q 111 / Q 111}$ striatal slices, as compared to that of $H d h^{\mathrm{Q} 20 / \mathrm{Q} 20}$ striatal slices (Fig. 5C,D).

To determine whether mGluR1/5 stimulation resulted in AKT activation in $H d h^{Q 111 / Q 111}$ striatal neurons, we stimulated neuronal primary cultures with $10 \mu \mathrm{M}$ DHPG and determined the levels of AKT phosphorylation. 5 min DHPG-stimulation led to an increase in AKT phosphorylation in both $H d h^{\mathrm{Q} 20 / \mathrm{Q} 20}$ and $H d h^{Q 111 / Q 111}$ neurons (Fig. 6A,B). However, basal AKT phosphorylation was significantly higher in $H d h^{\text {Q111/Q111 }}$ than in $H d h^{Q 20 / Q 20}$ neurons, suggesting that this signal transduction pathway was constitutively engaged in the neurons derived from $H d h^{Q 111 / Q 111}$ mice (Fig. 6A,B). Interestingly, this increase in basal AKT phosphorylation in $H d h^{Q 111 / Q 111}$ neurons was mGluR5dependent, as treatment of neurons with $10 \mu \mathrm{M}$ MPEP reduced basal AKT phosphorylation to $H d h^{\mathrm{Q} 20 / Q^{20}}$ levels (Fig. $6 A, B$ ). Together, these data indicated that mGluR5-dependent activation of cell survival signaling pathways was increased in neurons derived from $H d h^{Q 111 / Q 111}$ mice, despite the fact that InsP formation via the receptor was uncoupled as a consequence of PKC-mediated desensitization.

\section{PKC-mediated mGluR5 desensitization protects against neuronal cell death}

We observed that mGluR5-dependent activation of AKT in the absence of an agonist challenge was increased and agoniststimulated InsP formation was uncoupled in neurons derived from $H d h^{Q 111 / Q 111}$ mice. Therefore, we examined whether the

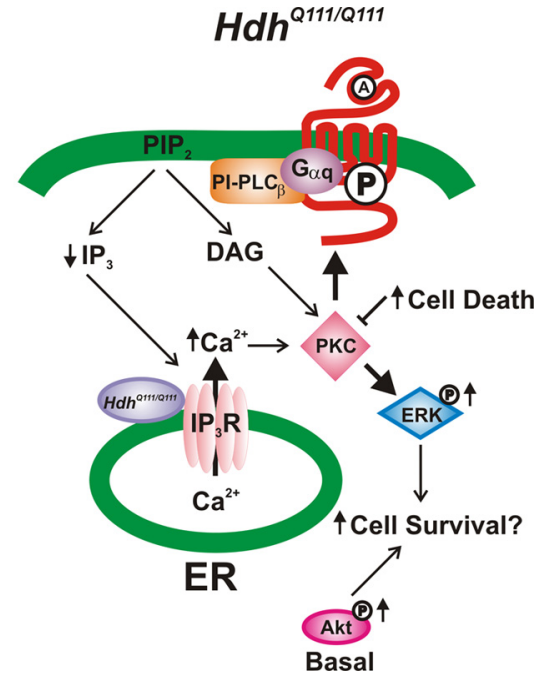

$H d h^{Q 20 / Q 20}$

(ब) (ब)

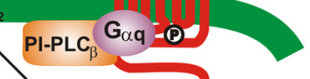

DAG
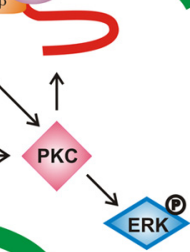

$\mathrm{Ca}^{2+}$

ER

Figure 8. Schematic representation of the proposed model for $\mathrm{mGluR} 1 / 5$ signaling alterations in HD. Shown is a schematic for mGluR1/5 signaling in $H d h^{020 / 020}$ and $H d h^{0111 / 0111}$ mice. mGluR1/5 are coupled to $\mathrm{G} \alpha_{\mathrm{q} / 11}$ proteins, and its activation results in diacylglycerol (DAG) and IP3 formation, release of $\mathrm{Ca}^{2+}$ from intracellular stores and activation of PKC, as well as activation of ERK mice, mGluRT/5-mediated $1 \mathrm{P} 3$ formation is decreased due to increased PKC-mediated mGluR1/5 desencreased in $H d h^{0111 / 0111}$ mice, as compared to $H d h^{020 / 020}$ mice. This is likely the consequence of an adaptive response in an attempt to keep $H d h^{0111 / 0111}$ neurons alive in the presymptomatic phase of the disease. Inhibition of PKC leads to increased DHPGstimulated cell death in neurons derived from $H d h^{0111 / 0111}$ mice, as compared to $H d h^{020 / 020}$ mice.

alterations in mGluR5 signaling observed in presymptomatic $H d h^{Q 111 / Q 111}$ mice may contribute to enhanced neuroprotection of $H d h^{Q 111 / Q 111}$ neurons. We found that cell death in response to the treatment of striatal neurons with $250 \mu \mathrm{M}$ glutamate for $24 \mathrm{~h}$ was not different for cultures derived from $H d h^{\mathrm{Q} 20 / \mathrm{Q} 20}, H d h^{\mathrm{Q} 111 / \mathrm{Q} 111}$,

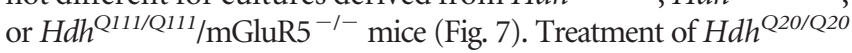
neurons with $100 \mu \mathrm{M}$ DHPG or PKC inhibitor ( $1 \mu \mathrm{M}$ Bis I), either alone or in the presence of $100 \mu \mathrm{M}$ DHPG, resulted in no increase in neuronal cell death, as compared to untreated $H_{d h}{ }^{\mathrm{Q} 20 / \mathrm{Q} 20}$ neurons (Fig. 7). Furthermore, treatment of striatal neurons derived from $H d h^{Q 111 / Q 111}$ mice with either $100 \mu \mathrm{M}$ DHPG or $1 \mu \mathrm{M}$ Bis I alone failed to induce neuronal cell death (Fig. 7). However, when $H d h^{Q 111 / Q 111}$ neurons were treated with $100 \mu \mathrm{M}$ DHPG in presence of a PKC inhibitor, a significant increase in neuronal cell death was observed, as compared to that of matched treated $H d h^{\mathrm{Q} 20 / \mathrm{Q} 20}$ neurons (Fig. 7). No increase in neuronal cell death was observed in striatal neuronal cultures derived from $H d h^{Q 111}$ Q111 lacking mGluR5 $\left(^{-1-}\right)$ in response to DHPG in the presence of Bis I (Fig. 7). Thus the increased level in neuronal cell death observed in Hdh Q111/Q111 mice treated with DHPG and Bis I was mGluR5-dependent, demonstrating that altered mGluR5 signal transduction may be neuroprotective in the presymptomatic phase of the disease.

\section{Discussion}

The neuronal cell loss that takes place in the striatum and cortex of HD patients is considered to be the primary cause of HD symptoms and eventual death of HD patients (Vonsattel et al., 1985; Vonsattel and DiFiglia, 1998). It is still not clear why mutant Htt protein leads to selective neuronal cell death and why there is a delayed loss of neurons late in life. mGluR1/5 can signal to activate different pathways that can be either protective or exacerbate neuronal cell death (Nicoletti et al., 1996; Bruno et al., 2001; Tang et al., 2003; Baskys et al., 2005). In the present study, we show that mGluR1/5 signaling pathways are altered in the presymptomatic phase of a $H d h^{Q 111 / Q 111}$ knock-in mouse model 
of HD (Fig. 8). DHPG-mediated InsP formation is significantly reduced in $H d h^{Q 111 / Q 111}$ mice, when compared to $H d h^{\mathrm{Q} 20 / \mathrm{Q} 20}$ mice, and this attenuation of InsP signaling is PKC-dependent. Furthermore, activation of protective pathways involving ERK and AKT is augmented in $H d h^{Q 111 / Q 111}$ neurons, as compared to $H d h^{Q 20 / Q 20}$ neurons, which indicates an early integral adaptive response to protect against cell death. PKC inhibition leads to increased DHPG-stimulated neuronal cell death in $H d h^{\text {Q111/Q111 }}$ neurons, suggesting that PKC-mediated mGluR1/5 desensitization in $H d h^{Q 111 / Q 111}$ neurons might be protective.

DHPG-mediated $\mathrm{Ca}^{2+}$ release is sensitized in $H d h^{Q 111 / Q 111}$ neurons when compared to $H d h^{\mathrm{Q} 20 / \mathrm{Q} 20}$ neuronal cultures, despite the fact that DHPG-mediated InsP formation is reduced in $H d h^{Q 11 / Q 111}$ neurons. These results are in agreement with published results showing increased $\mathrm{Ca}^{2+}$ release in a YAC128 HD transgenic mouse model (Tang et al., 2005). At least three different mechanisms account for the increase in intracellular $\mathrm{Ca}^{2+}$ release in transgenic HD mouse models: (1) mutated Htt protein may cause the sensitization of the NDMA receptor permeability, resulting in an increase in extracellular $\mathrm{Ca}^{2+}$ entrance into neurons (Chen et al., 1999; Sun et al., 2001); (2) mutated Htt protein may destabilize mitochondrial $\mathrm{Ca}^{2+}$ regulation (Panov et al., 2002; Choo et al., 2004); or (3) mutated Htt protein sensitizes the inositol-1,4,5-triphosphate (IP3) receptor-mediated release of $\mathrm{Ca}^{2+}$ from intracellular stores (Tang et al., 2005). In the present study, $H d h^{Q 111 / Q 111}$ neurons exhibit enhanced sensitivity for intracellular $\mathrm{Ca}^{2+}$ release in response to DHPG treatment, which may be the underlying mechanism responsible for enhanced ERK phosphorylation in DHPG-treated $H d h^{\mathrm{Q} 111 / \mathrm{Q} 111}$ neurons.

mGluR5-mediated ERK activation in striatal neurons occurs as the consequence of either InsP-stimulated $\mathrm{Ca}^{2+}$ release, the activation of Pyk2 or Homer proteins (Mao et al., 2005) (A. A. Nicodemo and S. S. G. Ferguson, unpublished observations). Interestingly, Homer is important for mGluR5-mediated ERK activation in the striatum and spinal cord, but Homer does not appear to contribute to mGluR5 activation of ERK in the hippocampus (Mao et al., 2005; Tappe et al., 2006; Ronesi and Huber, 2008). Thus, in addition to increased $\mathrm{Ca}^{2+}$ release, Homer may also be contributing to increased DHPG-stimulated ERK1/2 phosphorylation in $H d h^{Q 111 / Q 111}$ striatal neurons.

It has been shown that basal levels of AKT phosphorylation are increased in an immortalized $H d h^{\text {Q111/Q111 }}$ striatal cell line (Gines et al., 2003). The increase in basal AKT phosphorylation in $H d h^{Q 111 / Q 111}$ striatal cells has been shown to be NMDA receptor (NMDAR)-dependent, as the NMDAR antagonist MK801 decreases $H d h^{Q 111 / Q 111}$ AKT phosphorylation to control levels (Gines et al., 2003). We show here that the mGluR5 selective antagonist MPEP also suppresses basal AKT phosphorylation in neurons derived from $H d h^{Q 111 / Q 111}$ mice. Therefore, in addition to NMDAR activation, altered mGluR5 signaling may also underlie increased AKT signaling in $H d h^{Q 111 / Q 111}$ knock-in mice and may represent a neuroprotective signaling response. The activation of AKT by mGluR5 involves phosphoinositide 3-kinase (PI3K) and phosphoinositide-dependent kinase (PDK1) (Rong et al., 2003; Hou and Klann, 2004). mGluR1 activation leads to formation of the functional complex mGluR1-Homer-PIKE (PI3K enhancer), allowing PI3 kinase activation by PIKE, which results in reduced apoptosis (Rong et al., 2003). The observation that the increase in basal AKT activation in $H d h^{Q 111 / Q 111}$ striatal neurons can be blocked using a mGluR5-specific antagonist suggests that mGluR5 signaling via AKT is selectively enhanced in the absence of basal alterations in ERK and InsP signaling. Phosphorylation of AKT by glutamate receptors is particularly impor- tant because it has been shown that AKT activation can protect against neuronal death (Datta et al., 1999; Kandel and Hay, 1999). Furthermore, AKT can also promote phosphorylation of mutated Htt protein, which functions to reduce $\mathrm{Htt}$ aggregate formation and neuronal cell death, providing a protective pathway in HD (Humbert et al., 2002; Warby et al., 2009).

The glutamatergic system plays a substantial role in neuronal cell death and there are consistent data implicating ionotropic glutamate receptor activation with the excitotoxic neuronal loss in HD (Zeron et al., 2002; Schiefer et al., 2004). Some studies suggest that the sensitization of the NMDAR containing the subunit NR1/NR2B by the mutated Htt protein is responsible for causing the selective cell death of the medium sized spiny neurons present in the striatum, since these neurons express high level of this NMDAR subtype (Chen et al., 1999; Zeron et al., 2001). Group I mGluR receptors have also been implicated in neuronal cell death. However, there are mixed reports with respect to the role of mGluRs. Treatment of an HD transgenic mouse model with mGluR5 antagonists increases survival (Schiefer et al., 2004). The disruption of calcium signaling and increased neuronal apoptosis that are observed in medium sized spiny neurons of an HD mouse model are also attributed to activation of mGluR1/5 and NMDAR containing the NR2B subunit (Tang et al., 2005). However, other studies have provided evidence that mGluR signaling may be protective. For example, when cortical neuronal cultures are consecutively incubated two times with DHPG, NMDAR-mediated excitotoxicity is attenuated (Bruno et al., 2001; Baskys et al., 2005). The results presented here demonstrate that DHPG-mediated InsP formation is reduced in $H d h^{Q 111 / Q 111}$ mice due to an increase in PKC-mediated desensitization of mGluR1/5 in $H d h^{Q 111 / Q 111}$ mice. It is possible that the PKC-mediated mGluR1/5 desensitization is protective, avoiding further increases in calcium release that may result in increased cell death. We find that basal levels of cell death are the same in neuronal primary cultures obtained from $H d h^{\mathrm{Q} 20 / \mathrm{Q} 20}$ and $H d h^{Q 111 / Q 111}$ embryos. However, when PKC-mediated mGluR1/5 desensitization is blocked with the PKC inhibitor Bis I, DHPG stimulation causes an increase in $H d h^{Q 111 / Q 111}$ neuronal death, although it does not enhance $H d h^{\mathrm{Q} 20 / \mathrm{Q} 20}$ neuronal death.

PKC-mediated mGluR1/5 desensitization is present only in the asymptomatic phase of the disease, disappearing in mice older than 11 months. Furthermore, the data presented here demonstrate that mGluR1/5-mediated ERK and AKT activation, which can be protective against neuronal cell death, was higher in $H d h^{Q 111 / Q 111}$ neurons than in $H d h^{Q 20 / Q 20}$ neurons. These data might shed some light on why HD symptoms only appear later in life, although the mutated Htt protein is expressed since the beginning of patient's life. It is possible that mGluR1/5-mediated signaling pathways that could lead to cell death (increase in intracellular calcium) are desensitized and that pathways that could lead to neuronal protection (activation of ERK and AKT) are sensitized in the asymptomatic phase of the disease. These alterations might be lost later in life, causing an increase in neuronal death and the development of HD symptoms.

\section{References}

Alagarsamy S, Marino MJ, Rouse ST, Gereau RW 4th, Heinemann SF, Conn PJ (1999) Activation of NMDA receptors reverses desensitization of mGluR5 in native and recombinant systems. Nat Neurosci 2:234-240.

Alagarsamy S, Saugstad J, Warren L, Mansuy IM, Gereau RW 4th, Conn PJ (2005) NMDA-induced potentiation of mGluR5 is mediated by activation of protein phosphatase 2B/calcineurin. Neuropharmacology 49 [Suppl 1]:135-145.

Anborgh PH, Godin C, Pampillo M, Dhami GK, Dale LB, Cregan SP, Truant 
R, Ferguson SS (2005) Inhibition of metabotropic glutamate receptor signaling by the huntingtin-binding protein optineurin. J Biol Chem 280:34840-34848.

Baskys A, Bayazitov I, Fang L, Blaabjerg M, Poulsen FR, Zimmer J (2005) Group I metabotropic glutamate receptors reduce excitotoxic injury and may facilitate neurogenesis. Neuropharmacology 49 [Suppl 1]:146-156.

Beal MF, Ferrante RJ, Swartz KJ, Kowall NW (1991) Chronic quinolic acid lesions in rats closely resemble Huntington's disease. J Neurosci 11:1649-1659.

Bruno V, Battaglia G, Copani A, Cespédes VM, Galindo MF, Ceña V, Sánchez-Prieto J, Gasparini F, Kuhn R, Flor PJ, Nicoletti F (2001) An activity-dependent switch from facilitation to inhibition in the control of excitotoxicity by group I metabotropic glutamate receptors. Eur J Neurosci 13:1469-1478.

Calabresi P, Centonze D, Pisani A, Bernardi G (1999) Metabotropic glutamate receptors and cell-type-specific vulnerability in the striatum: implication for ischemia and Huntington's disease. Exp Neurol 158:97-108.

Catania MV, Aronica E, Sortino MA, Canonico PL, Nicoletti F (1991) Desensitization of metabotropic glutamate receptors in neuronal cultures. J Neurochem 56:1329-1335.

Chen N, Luo T, Wellington C, Metzler M, McCutcheon K, Hayden MR, Raymond LA (1999) Subtype-specific enhancement of NMDA receptor currents by mutant huntingtin. J Neurochem 72:1890-1898.

Choo YS, Johnson GV, MacDonald M, Detloff PJ, Lesort M (2004) Mutant huntingtin directly increases susceptibility of mitochondria to the calcium-induced permeability transition and cytochrome $\mathrm{c}$ release. Hum Mol Genet 13:1407-1420.

Conn PJ, Pin JP (1997) Pharmacology and functions of metabotropic glutamate receptors. Annu Rev Pharmacol Toxicol 37:205-237.

Datta SR, Brunet A, Greenberg ME (1999) Cellular survival: a play in three Akts. Genes Dev 13:2905-2927.

Dhami GK, Ferguson SS (2006) Regulation of metabotropic glutamate receptor signaling, desensitization and endocytosis. Pharmacol Ther 111:260-271.

Dhami GK, Anborgh PH, Dale LB, Sterne-Marr R, Ferguson SS (2002) Phosphorylation-independent regulation of metabotropic glutamate receptor signaling by $\mathrm{G}$ protein-coupled receptor kinase 2. J Biol Chem 277:25266-25272.

Dhami GK, Babwah AV, Sterne-Marr R, Ferguson SS (2005) Phosphorylationindependent regulation of metabotropic glutamate receptor 1 signaling requires $g$ protein-coupled receptor kinase 2 binding to the second intracellular loop. J Biol Chem 280:24420-24427.

DiFiglia M (1990) Excitotoxic injury of the neostriatum: a model for Huntington's disease. Trends Neurosci 13:286-289.

Fortin A, Cregan SP, MacLaurin JG, Kushwaha N, Hickman ES, Thompson CS, Hakim A, Albert PR, Cecconi F, Helin K, Park DS, Slack RS (2001) APAF1 is a key transcriptional target for p53 in the regulation of neuronal cell death. J Cell Biol 155:207-216.

Gines S, Ivanova E, Seong IS, Saura CA, MacDonald ME (2003) Enhanced Akt signaling is an early pro-survival response that reflects N-methyl-Daspartate receptor activation in Huntington's disease knock-in striatal cells. J Biol Chem 278:50514-50522.

Grewal SS, York RD, Stork PJ (1999) Extracellular-signal-regulated kinase signalling in neurons. Curr Opin Neurobiol 9:544-553.

Grynkiewicz G, Poenie M, Tsien RY (1985) A new generation of Ca2 + indicators with greatly improved fluorescence properties. J Biol Chem 260:3440-3450.

Hou L, Klann E (2004) Activation of the phosphoinositide 3-kinase-Aktmammalian target of rapamycin signaling pathway is required for metabotropic glutamate receptor-dependent long-term depression. J Neurosci 24:6352-6361.

Humbert S, Bryson EA, Cordelières FP, Connors NC, Datta SR, Finkbeiner S, Greenberg ME, Saudou F (2002) The IGF-1/Akt pathway is neuroprotective in Huntington's disease and involves Huntingtin phosphorylation by Akt. Dev Cell 2:831-837.

Kandel ES, Hay N (1999) The regulation and activities of the multifunctional serine/threonine kinase Akt/PKB. Exp Cell Res 253:210-229.

LiSH, Li XJ (2004) Huntingtin-protein interactions and the pathogenesis of Huntington's disease. Trends Genet 20:146-154.

Lu YM, Jia Z, Janus C, Henderson JT, Gerlai R, Wojtowicz JM, Roder JC (1997) Mice lacking metabotropic glutamate receptor 5 show impaired learning and reduced CA1 long-term potentiation (LTP) but normal CA3 LTP. J Neurosci 17:5196-5205.

Mao L, Yang L, Tang Q, Samdani S, Zhang G, Wang JQ (2005) The scaffold protein Homer1b/c links metabotropic glutamate receptor 5 to extracel- lular signal-regulated protein kinase cascades in neurons. J Neurosci 25:2741-2752.

Nakanishi S (1994) Metabotropic glutamate receptors: synaptic transmission, modulation, and plasticity. Neuron 13:1031-1037.

Nicoletti F, Bruno V, Copani A, Casabona G, Knöpfel T (1996) Metabotropic glutamate receptors: a new target for the therapy of neurodegenerative disorders? Trends Neurosci 19:267-271.

Panov AV, Gutekunst CA, Leavitt BR, Hayden MR, Burke JR, Strittmatter WJ, Greenamyre JT (2002) Early mitochondrial calcium defects in Huntington's disease are a direct effect of polyglutamines. Nat Neurosci 5:731-736.

Pin JP, Duvoisin R (1995) The metabotropic glutamate receptors: structure and functions. Neuropharmacology 34:1-26.

Ribeiro FM, Pinthong M, Black SA, Gordon AC, Prado VF, Prado MA, Rylett RJ, Ferguson SS (2007) Regulated recycling and plasma membrane recruitment of the high-affinity choline transporter. Eur J Neurosci 26:3437-3448.

Ribeiro FM, Ferreira LT, Paquet M, Cregan T, Ding Q, Gros R, Ferguson SS (2009) Phosphorylation-independent regulation of metabotropic glutamate receptor 5 desensitization and internalization by $\mathrm{G}$ protein-coupled receptor kinase 2 in striatal neurons. J Biol Chem 284:23444-23453.

Romano C, Sesma MA, McDonald CT, O’Malley K, Van den Pol AN, Olney JW (1995) Distribution of metabotropic glutamate receptor mGluR5 immunoreactivity in rat brain. J Comp Neurol 355:455-469.

Ronesi JA, Huber KM (2008) Homer interactions are necessary for metabotropic glutamate receptor-induced long-term depression and translational activation. J Neurosci 28:543-547.

Rong R, Ahn JY, Huang H, Nagata E, Kalman D, Kapp JA, Tu J, Worley PF, Snyder SH, Ye K (2003) PI3 kinase enhancer-Homer complex couples mGluRI to PI3 kinase, preventing neuronal apoptosis. Nat Neurosci 6:1153-1161.

Schiefer J, Sprünken A, Puls C, Lüesse HG, Milkereit A, Milkereit E, Johann V, Kosinski CM (2004) The metabotropic glutamate receptor 5 antagonist MPEP and the mGluR2 agonist LY379268 modify disease progression in a transgenic mouse model of Huntington's disease. Brain Res 1019:246-254.

Sun Y, Savanenin A, Reddy PH, Liu YF (2001) Polyglutamine-expanded huntingtin promotes sensitization of $\mathrm{N}$-methyl-D-aspartate receptors via post-synaptic density 95. J Biol Chem 276:24713-24718.

Tang TS, Tu H, Chan EY, Maximov A, Wang Z, Wellington CL, Hayden MR, Bezprozvanny I (2003) Huntingtin and huntingtin-associated protein 1 influence neuronal calcium signaling mediated by inositol- $(1,4,5)$ triphosphate receptor type 1. Neuron 39:227-239.

Tang TS, Slow E, Lupu V, Stavrovskaya IG, Sugimori M, Llinás R, Kristal BS, Hayden MR, Bezprozvanny I (2005) Disturbed Ca2 + signaling and apoptosis of medium spiny neurons in Huntington's disease. Proc Natl Acad Sci U S A 102:2602-2607.

Tappe A, Klugmann M, Luo C, Hirlinger D, Agarwal N, Benrath J, Ehrengruber MU, During MJ, Kuner R (2006) Synaptic scaffolding protein Homerla protects against chronic inflammatory pain. Nat Med 12:677-681.

The Huntington's Disease Collaborative Research Group (1993) A novel gene containing a trinucleotide repeat that is expanded and unstable on Huntington's disease chromosomes. Cell 72:971-983.

Vonsattel JP, DiFiglia M (1998) Huntington disease. J Neuropathol Exp Neurol 57:369-384.

Vonsattel JP, Myers RH, Stevens TJ, Ferrante RJ, Bird ED, Richardson EP Jr (1985) Neuropathological classification of Huntington's disease. J Neuropathol Exp Neurol 44:559-577.

Warby SC, Doty CN, Graham RK, Shively J, Singaraja RR, Hayden MR (2009) Phosphorylation of huntingtin reduces the accumulation of its nuclear fragments. Mol Cell Neurosci 40:121-127.

Wheeler VC, Auerbach W, White JK, Srinidhi J, Auerbach A, Ryan A, Duyao MP, Vrbanac V, Weaver M, Gusella JF, Joyner AL, MacDonald ME (1999) Length-dependent gametic CAG repeat instability in the Huntington's disease knock-in mouse. Hum Mol Genet 8:115-122.

Young AB (2003) Huntingtin in health and disease. J Clin Invest 111:299-302.

Zeron MM, Chen N, Moshaver A, Lee AT, Wellington CL, Hayden MR, Raymond LA (2001) Mutant huntingtin enhances excitotoxic cell death. Mol Cell Neurosci 17:41-53.

Zeron MM, Hansson O, Chen N, Wellington CL, Leavitt BR, Brundin P, Hayden MR, Raymond LA (2002) Increased sensitivity to N-methyl-Daspartate receptor-mediated excitotoxicity in a mouse model of Huntington's disease. Neuron 33:849-860. 